\title{
Macrophage/Microglial-mediated Primary Demyelination and Motor Disease Induced by the Central Nervous System Production of Interleukin-3 in Transgenic Mice
}

\author{
Chi-Shiun Chiang, ${ }^{*}$ Henry C. Powell, ${ }^{\ddagger}$ Lisa H. Gold, ${ }^{*}$ Ana Samimi, ${ }^{*}$ and lain L. Campbell ${ }^{\star}$ \\ *Department of Neuropharmacology, The Scripps Research Institute, La Jolla, California 92037; ${ }^{\ddagger}$ Veterans Administration Research \\ Service and Department of Pathology, University of California San Diego, La Jolla, California 92093-0612
}

\begin{abstract}
Activated macrophage/microglia may mediate tissue injury in a variety of CNS disorders. To examine this, transgenic mice were developed in which the expression of a macrophage/ microglia activation cytokine, interleukin-3 (IL-3), was targeted to astrocytes using a murine glial fibrillary acidic protein fusion gene. Transgenic mice with low levels of IL-3 expression developed from 5 mo of age, a progressive motor disorder characterized at onset by impaired rota-rod performance. In symptomatic transgenic mice, multi-focal, plaquelike white matter lesions were present in cerebellum and brain stem. Lesions showed extensive primary demyelination and remyelination in association with the accumulation of large numbers of proliferating and activated foamy macrophage/microglial cells. Many of these cells also contained intracisternal crystalline pole-like inclusions similar to those seen in human patients with multiple sclerosis. Mast cells were also identified while lymphocytes were rarely, if at all present. Thus, chronic CNS production of low levels of IL-3 promotes the recruitment, proliferation and activation of macrophage/microglial cells in white matter regions with consequent primary demyelination and motor disease. This transgenic model exhibits many of the features of human inflammatory demyelinating diseases including multiple sclerosis and HIV leukoencephalopathy. (J. Clin. Invest. 1996. 97:1512-1524.) Key words: neurologic disease • multiple sclerosis - inflammation - cytokine - glial fibrillary acidic protein
\end{abstract}

\section{Introduction}

Microglia are central nervous system $(\mathrm{CNS})^{1}$ resident, macrophage-derived cells that comprise $10-20 \%$ of the normal

Address correspondence to Dr. Iain L. Campbell, Department of Neuropharmacology, CVN 9, The Scripps Research Institute, 10666 North Torrey Pines Road, La Jolla, CA 92037. Phone: 619-784-7092; FAX: 619-784-7377; E-Mail: icamp@scripps.edu. Chi-Shiun Chiang's present address is Department of Nuclear Science, Tsing-Hua University, Hisn-Shu, 300043, Taiwan.

Received for publication 14 September 1995 and accepted in revised form 20 December 1995.

1. Abbreviations used in this paper: CNPase, 2', 3' Cyclic Nucleotide Phosphohydrolase; CNS, central nervous system; EAE, experimental allergic encephalomyelitis; GFAP, glial fibrillary acidic protein; MBP, myelin basic protein.

J. Clin. Invest.

(C) The American Society for Clinical Investigation, Inc.

0021-9738/96/03/1512/13 \$2.00

Volume 97, Number 6, March 1996, 1512-1524 adult brain glial cells and exist largely in a resting state (1-3). These cells become functionally activated when the brain is injured or in the course of neurodegenerative disease. Pronounced activation of the macrophage/microglia in the CNS has been associated with many disorders such as multiple sclerosis (MS) (4), Parkinson's dementia (5), Alzheimer dementia (6), human immunodeficiency virus (HIV)-associated dementia (7) and radiation-induced CNS injury (8). Activation of microglia may play a role in host defense, e.g., immune activation or tissue repair, and this process could also be harmful, contributing to CNS tissue injury (3,9-11). In support of the latter view, these cells are known to produce a number of soluble factors, including cytokines, prostaglandins, and free radicals (for reviews see references 7,10, and 12), that are toxic to neurons in vitro. In spite of this largely circumstantial evidence, definitive information concerning the potential neuropathogenic actions of activated microglia is lacking, as are suitable animal models for studying the role of these cells in CNS disease.

Interleukin 3 (IL-3) was originally described as a T cellderived cytokine (for review see reference 13) that acted as a hematopoietic growth factor supporting the proliferation of multipotential progenitors at the early stages of their differentiation. Subsequently, IL-3 was shown to possess potent macrophage-activating properties associated with $\mathrm{T}$ cell-dependent immune responses (14), (15). As a growth factor in the development of hematopoietic progenitor cells as well as mature neutrophils, eosinophils and macrophages in the bone marrow and peripheral circulation, IL-3 has been used in clinical trials in the treatment of pancytopenic disorders (16-18). Consistent with its immune regulatory properties, tumors engineered to produce murine IL-3 become heavily infiltrated by macrophages and granulocytes $(19,20)$. In the CNS, microglia have been reported to produce and respond to IL-3 (21). Expression of the $\beta$ subunit (signal transducing) of the IL-3 receptor shows restricted distribution in the rat brain, being expressed by only macrophage/microglial cells (22). IL-3 also acts on microglia in vitro, inducing proliferation and multinucleated giant cell formation (23). Moreover, a recent report found IL-3 was detectable in post mortem brain tissue from patients with Alzheimer's disease (24). Therefore, IL-3 may play a role in the marked activation of microglia and subsequent development of neurodegeneration seen in this disease.

The development of animal models for the spontaneous and chronic activation of the CNS microglia would greatly advance attempts at better understanding the biology and pathobiology of these cells. To this end, in the present study we utilized a previously well defined transgenic approach $(25,26)$ using a glial fibrillary acidic protein (GFAP) expression cassette to direct the constitutive expression of the macrophage/ microglial activating cytokine, IL-3, to astrocytes in the intact CNS of mice. The results indicate that so-called GFAP-IL3 transgenic mice with low levels of cerebral IL-3 expression de- 
velop in later life a progressive motor disorder as a result of a vigorous $\mathrm{T}$ cell-independent macrophage/microglia-mediated demyelination process. The molecular and cellular CNS manifestations of this disorder resemble many of those observed in human inflammatory demyelinating disorders. Therefore, the GFAP-IL3 transgenic mouse represents a novel experimental model to study the role of macrophage/microglia in the pathogenesis of CNS demyelinating disease.

\section{Methods}

Generation of GFAP-IL3 transgenic mice. The overall strategy used for the generation of the GFAP-IL3 transgenic mice followed that described previously for the generation of GFAP-IL6 transgenic mice (26). The CNS and astrocyte specific expression obtained for fusion gene constructs under the control of this promoter is well documented $(26,27)$. Briefly, a full length cDNA encoding murine IL-3 (kindly provided by Dr. John Schrader, University of British Columbia, Vancouver, Canada) was modified by removal of the 3' untranslated region. After the addition of Not-1 linkers the modified IL-3 cDNA fragment was subcloned into the Not I-digested vector pCMV (Clontech, Palo Alto, CA). A clone containing the cDNA in the correct orientation was selected and the IL-3 cDNA together with the upstream SV-40 splice donor/acceptor site and the downstream SV40 polyadenylation signal was excised using Xho I/Sal I. This fragment was then inserted into the unique SalI restriction enzyme site of the modified murine GFAP gene used previously for IL-6 (26).

After screening for correct orientation, the GFAP-IL3 fusion gene construct was excised and purified from plasmid DNA before microinjection into fertilized eggs of $(\mathrm{C} 57 \mathrm{BL} / 6 \mathrm{~J} \times \mathrm{SJL}) \mathrm{F} 1$ hybrid mice. Transgenic offspring were identified by slot-blot analysis of tail DNA using a ${ }^{32} \mathrm{P}$-labeled SV-40 late-region cDNA fragment as a probe.

Motor function test. Motor function was assessed using a rota-rod apparatus. Rota-rod balancing requires a variety of proprioceptive, vestibular, and fine tuned motor abilities. This task has been used successfully for detecting acute drug-induced changes in motor coordination as well as neurotoxicity produced by drugs and developmental behavioral abnormalities $(28,29)$.

The rota-rod apparatus consisted of a rotating horizontal cylinder $(30 \mathrm{~mm})$ and a motor driven control unit (Omnitech, Columbus, $\mathrm{OH})$. The cylinder was divided into 4 separate rotating compartments, fully enclosed to ensure that the mice did not jump out of their area. The mice were placed on the rod which was rotating at a fixed speed of 5 or 15 revolutions per minute (rpm). Automatic timers recorded the duration of time (in tenths of seconds) the mice remained on the rod, and two infrared beams at the base of each compartment determined when the mice had fallen off the rod. Each mouse was tested for three $180 \mathrm{~s}$ trials, with $1 \mathrm{~min}$ inter-trial interval at $5 \mathrm{rpm}$. After all the mice were tested at $5 \mathrm{rpm}$ they were then tested at 15 rpm (about 75 min later) for three $180 \mathrm{~s}$ trials, with 1-min inter-trial interval. All testing occurred in low light, during the dark portion of the light/dark cycle.

Rotating rod performance was analyzed by two-way analysis of variance (group and trial) with repeated measures on the trial factor followed by Newman-Keuls post hoc test.

$R N A$ isolation. Organs were removed and immediately snap-frozen in liquid nitrogen. Poly (A) ${ }^{+}$enriched RNA was isolated by a rapid procedure (30). Briefly, frozen organs were placed in lysis buffer (10 ml; $0.2 \mathrm{M} \mathrm{NaCl}, 0.2 \mathrm{M}$ Tris/ $\mathrm{HCl} \mathrm{pH}$ 7.5, $1.5 \mathrm{mM} \mathrm{MgCl}_{2}, 2 \%$ SDS, $200 \mu \mathrm{g} / \mathrm{ml}$ proteinase K) and immediately homogenized. After incubation for $60 \mathrm{~min}$ at $45^{\circ} \mathrm{C}$, the $\mathrm{NaCl}$ concentration of the lysate was adjusted to $0.5 \mathrm{M}$ and mixed with $40 \mathrm{mg}$ of oligo-dT cellulose (In Vitrogen, San Diego, CA) that had been pre-equilibrated in binding buffer $(0.5 \mathrm{M} \mathrm{NaCl}, 0.01 \mathrm{M}$ Tris/ $\mathrm{HCl} \mathrm{pH} 7.5)$. The mixture was then incubated at $25^{\circ} \mathrm{C}$ for $60 \mathrm{~min}$ with gentle rocking. After washing with binding buffer, poly (A) ${ }^{+}$RNA was eluted from the oligo-dT cellulose with elution buffer $(0.5 \mathrm{ml} ; 0.01 \mathrm{M}$ Tris $/ \mathrm{HCl} \mathrm{pH} \mathrm{7.5)}$ and precipitated in ethanol, dried and resuspended in $25 \mu \mathrm{l}$ elution buffer. The concentration of RNA was determined by UV spectroscopy at $260 \mathrm{~nm}$.

RNase protection assays. RPA for the detection of cytokine RNAs was performed as described previously (31-33).

Northern blot analysis. Poly (A) ${ }^{+}$RNA $(5 \mu \mathrm{g})$ was denatured, electrophoresed in $1 \%$ agarose $/ 2.2 \mathrm{M}$ formaldehyde gels, transferred to nylon membranes, pre-hybridized in hybridization buffer (HB) (6× SSPE, pH 7.6, 50\% formamide, $5 \times$ Denhardt's solution, and $0.2 \%$ SDS) containing $10 \mu \mathrm{g} / \mathrm{ml}$ Salmon Sperm DNA at $45^{\circ} \mathrm{C}$ for $1 \mathrm{~h}$, and then hybridized overnight at $45^{\circ} \mathrm{C}$ with ${ }^{32} \mathrm{P}$-labeled cDNA probes. After autoradiographic exposure, the membrane was stripped twice in boiling water and hybridized with a different probe. Probes used were: a 932-bp cDNA fragment corresponding to the murine $\mathrm{Ia}^{\mathrm{b}} \alpha$ chain (34), a 600-bp cDNA fragment corresponding to the murine $\mathrm{H}-2 \mathrm{D}^{\mathrm{b}}(35)$ and a 0.26 -kb fragment of $\beta$-actin gene fragment (36) generated by PCR was provided by M. Nerenberg (The Scripps Research Institute, La Jolla, CA).

In situ hybridization. Animals were anesthetized and then slowly perfused intracardially with ice-cold PBS $(30 \mathrm{ml})$ followed by ice-cold $4 \%$ paraformaldehyde in PBS $(30 \mathrm{ml})$. After perfusion, the brain was removed and placed in ice-cold $4 \%$ paraformaldehyde $/ 1 \times \mathrm{PBS}$ (phosphate-buffered saline, $\mathrm{pH}$ 7.3). After overnight fixation, brains were processed, embedded in paraffin and $8-\mu \mathrm{m}$ sagittal sections prepared. All subsequent procedures for in situ hybridization were as described (37). ${ }^{35} \mathrm{~S}$-labeled cRNA to IL-3 was used as probe. The IL-3 probe was generated from a pBluescript $\mathrm{SK}+/-$ vector that contains an EcoRI/BglII fragment of the murine IL-3 cDNA used to make the GFAP fusion gene described above.

Immunocytochemical analysis. For the detection of Mac-1, CD4, CD8, B220, or Ia, mice were sacrificed by cervical dislocation and the brain was immediately removed, embedded in O.T.C medium, and snap frozen. Sagittal sections $(10 \mu \mathrm{m})$ were cut on a cryomicrotome, air-dried and stored at $-70^{\circ} \mathrm{C}$. Immediately before staining, sections were fixed in cold $\left(-20^{\circ} \mathrm{C}\right)$ methanol:acetone $(1: 1)$ solution for $1 \mathrm{~min}$ and then incubated for $20 \mathrm{~min}$ in PBS containing $2 \%$ FCS (to reduce nonspecific reactivity). Sections were incubated first with rat monoclonal antibody to: Mac-1 (ATCC,TIB126, Rockville, MD), CD4 (L3T4; Pharmingen), CD8 $\alpha$ (Ly-2; Pharmingen, San Diego, CA), B220 (CD45R, Pharmingen, San Diego, CA), or Ia (Clone MS/114, Boehringer-Mannheim Indianapolis, IN), respectively, for $1 \mathrm{~h}$ at room temperature. For GFAP immunostaining, brain was fixed in $70 \%$ alcohol overnight at $4^{\circ} \mathrm{C}$, embedded in paraffin, and sagittal sections $(4 \mu \mathrm{m})$ cut. The antibody used was a polyclonal rabbit antibovine GFAP (DAKO, Santa Barbara, CA). For all sections, bound antibody was detected with a biotinylated anti-rat or rabbit antibody followed by avidin labeled horseradish peroxidase (Sigma Chemical Co., St. Louis, MO) or alkaline phosphatase (Sigma Chemical Co.). Staining employed $3^{\prime}, 3^{\prime}$ diaminobenzidine (Sigma Chemical Co.) as substrate. Before mounting, sections were counter stained in Mayers hematoxylin (Sigma Chemical Co.).

Light and electron microscopy. Unless stated otherwise morphological examination of the brain was performed on $\mathrm{G} 3 \mathrm{C} 2$ mice and age-and sex-matched normal littermates. Before killing, animals were anesthetized with an intraperitoneal injection $(2 \mathrm{ml} / \mathrm{kg})$ of a solution consisting of pentobarbital $(12.5 \mathrm{mg} / \mathrm{ml})$ and diazepam $(1.25 \mathrm{mg} / \mathrm{ml})$ in $0.9 \% \mathrm{NaCl}$. Brains of some animals including the high expressor and G3K1 founder transgenic animals were removed for routine histology and light microscopic examination using buffered paraformaldehyde as a fixative. Animals used for electron microscopy were anesthetized and perfused intracardially with a solution of $5 \%$ phosphate buffered glutaraldehyde. The brain was then removed and after overnight fixation at $4^{\circ} \mathrm{C}$, tissues were postfixed in a $1 \%$ aqueous osmium tetraoxide solution for $2 \mathrm{~h}$, dehydrated using a graded series of ethanols and prophylene oxide and infiltrated with resin. Overnight infiltration was followed by embedding in fresh araldite resin. Thick sections $(1 \mu \mathrm{m})$ were cut with glass knives and stained with paraphe- 
nylenediamine (PPD) or methylene blue azure II in preparation for light microscopic examination. Ultrathin sections from selected blocks were cut with a diamond knife and stained with uranyl acetate and lead citrate before electron microscopic examination.

Western blotting. For western blot analysis, mice were killed by cervical dislocation and the cerebellum and cortices were isolated and snap frozen. The tissue was weighed and homogenized by sonication in 10 volumes of $1 \%$ SDS. Samples were centrifuged at $14,000 \mathrm{rpm}$ for $30 \mathrm{~min}$, and the supernatant was collected. The protein concentration was determined by Bradford analysis using commercially available reagents (BioRad, Hercules, CA). Sample corresponding to 20 $\mu \mathrm{g}$ protein was fractionated by $15 \%$ SDS PAGE and transferred to a nylon membrane using a Mini-Protein II system (BioRad) performed according to the manufacturer's instructions. Equal loading and transfer of proteins was confirmed with amido black (Sigma Chemical Co.) staining of the membrane. The membrane was then incubated for $1 \mathrm{~h}$ with $5 \%$ blocking solution (nonfat milk powder, Bio$\mathrm{Rad}$ ) in Tris buffered saline with $0.1 \%$ Tween, $\mathrm{pH} 7.5$ (T-TBS) (BioRad). After three washes with T-TBS, the membrane was incubated for $1 \mathrm{~h}$ with a solution containing rabbit anti-bovine GFAP antibody (1:5000) (DAKO, Santa Barbara, CA) or rabbit antimurine CNPase (1:2000) (obtained from Dr. Monica Carson, The Scripps Research Institute). After washing with three changes of T-TBS, the membrane was incubated for $1 \mathrm{~h}$ with a horseradish peroxidase labeled goat anti-rabbit IgG antibody (Invitrogen), and the bound complex detected using an ECL kit (Amersham) performed according to the manufacturer's instructions. After autoradiograph exposure, the membrane was stripped in $0.5 \% \beta$-mercaptoethanol in T-TBS at $60^{\circ} \mathrm{C}$ for $30 \mathrm{~min}$, washed in T-TBS for $15 \mathrm{~min}$, and then incubated for $1 \mathrm{~h}$ with $5 \%$ blocking solution. The membrane then was re-probed for rabbit anti-bovine MBP (1:2000) (Chemicon, Temecula, CA) or rabbit anti-rat SNAP25 (1:2000) (obtained from Dr. Michael C. Wilson, The Scripps Research Institute). The relative change in the intensity of the individual protein bands was determined by densitometry (Personal Densitometer, Molecular Dynamics, Sunnyvale, CA).

Cell proliferation in vivo. Mice were injected intraperitoneally with $\left[{ }^{3} \mathrm{H}\right]$ thymidine $(2 \mu \mathrm{Ci} / \mathrm{g}$ of body weight $)\left(\left[{ }^{3} \mathrm{H}\right]\right.$ methyl-thymidine; Amersham) in $0.5 \mathrm{ml}$ of saline and were killed $4 \mathrm{~h}$ after injection by cervical dislocation. Brains were processed and immunostained for the Mac-1, Ia and GFAP proteins as described above. After staining, the sections were dehydrated through a series of graded alcohol solutions and air-dried. Slides were then coated with film emulsion (Type NTB3; Eastman Kodak Co., Rochester, NY) and placed in a light tight box at $4^{\circ} \mathrm{C}$ for $4 \mathrm{wk}$. The emulsion was developed in DEKTOL (Eastman Kodak Co.) fixed, and counterstained with Mayer's Hematoxylin solution (Sigma Chemical Co.). For visualization and photomicroscopy, slides were examined using dark-field or epiluminescence microscopy.

Astrocyte cultures and the determination of IL-3 production. Astrocyte cultures were prepared from individual neonatal ( $<48 \mathrm{~h}$ old $)$ offspring as described previously (38). Brain cells from the cerebrum or the cerebellum were seeded into three wells of a six-well plate (Costar Corp.) to which was added DME containing antibiotics and $10 \%$ fetal calf serum. The medium was changed twice weekly. At confluence fresh medium was added to the cultures and supernatant was collected $24 \mathrm{~h}$ later for IL-3 assay. IL-3 was measured by an ELISA method using a commercially available kit (Endogen, Boston, MA) that detects murine IL-3. The remaining cells were lysed in $1 \mathrm{ml}$ of $1 \% \mathrm{SDS}$ in $50 \mathrm{mM}$ Tris-HCl, $\mathrm{pH}$ 7.4. Protein concentration of lysate was determined by BioRad protein assay reagents (BioRad) performed according to the manufacturer's instructions.

Assay of 2', 3' cyclic nucleotide phosphodiesterase (CNPase) activity. CNPase activity was measured by the method of Prohaska et al. (39) as described previously (38). Brain tissue was homogenized in 9 volumes of $0.32 \mathrm{M}$ sucrose. Aliquots $(0.2 \mathrm{ml})$ of homogenate were mixed with $0.5 \%(\mathrm{wt} / \mathrm{vol})$ sodium deoxycholate in $0.2 \mathrm{M}$ Tris- $\mathrm{HCl} \mathrm{pH}$ $7.5(0.3 \mathrm{ml})$ and incubated for $10 \mathrm{~min}$ at $4^{\circ} \mathrm{C}$. The homogenates were diluted in three volumes of distilled water and the protein concentration measured as described above. Homogenates $(20 \mu \mathrm{g}$ protein) were incubated with $180 \mu \mathrm{l}$ of $10.5 \mathrm{mM} 2^{\prime}-3^{\prime}$ cAMP in $50 \mathrm{mM}$ Trismaleate $\mathrm{pH} 6.2$ for $10 \mathrm{~min}$ at $30^{\circ} \mathrm{C}$. The reaction was terminated by placing tubes in boiling water for $30 \mathrm{~s}$. The solutions were returned to $30^{\circ} \mathrm{C}$ and $0.1 \mathrm{ml}$ of $0.3 \mathrm{M}$ Tris, $\mathrm{pH} 9$ containing $21 \mathrm{mM} \mathrm{MgCl}_{2}$ and 0.72 units of alkaline phosphatase (Sigma Chemical Co.) was added and the mixture incubated at $30^{\circ} \mathrm{C}$ for $20 \mathrm{~min}$. A mixture of isobutanol and toluene (1:1) $(1.2 \mathrm{ml})$ was then added together with $1.2 \mathrm{ml}$ of $1.5 \%(\mathrm{wt} / \mathrm{vol})\left(\mathrm{NH}_{4}\right)_{6} \mathrm{MO}_{7} \mathrm{O}_{24} \cdot 4 \mathrm{H}_{2} \mathrm{O}$ in $0.5 \mathrm{M} \mathrm{H}_{2} \mathrm{SO}_{4}$. After $20 \mathrm{~min}$ of
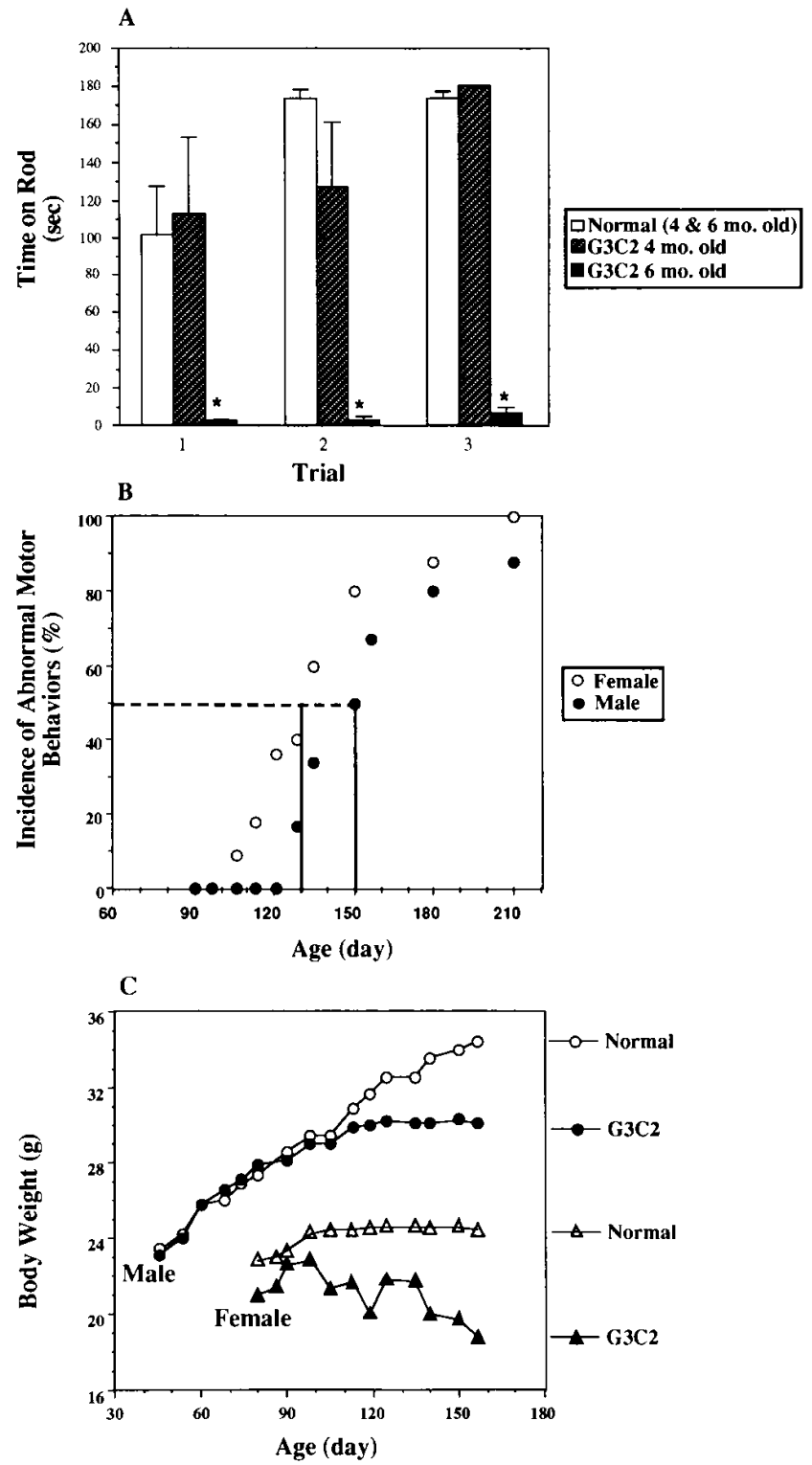

Figure 1. Altered physical characteristics of $\mathrm{G} 3 \mathrm{C} 2$ transgenic mice. (A) Impaired performance on a rotating rod $(5 \mathrm{rpm})$ in 6 month old G3C2 mice $(n=3)$ compared with that of 4-mo-old G3C2 mice $(n=$ $5)$ and normal littermates $(n=10)$. Values represent mean \pm SEM time spent on rotating rod for 3 trials with a maximum possible duration of $180 \mathrm{~s} /$ trial. $(B)$ Incidence of motor disease at different ages of $\mathrm{G} 3 \mathrm{C} 2$ mice. $(C)$ Body weight at different ages of $\mathrm{G} 3 \mathrm{C} 2$ compared with normal littermates. The data of $(B)$ and $(C)$ was obtained from 10 mice for each group. These mice were followed until the age of 7 mo. The incidence of abnormal motor behavior, e.g. head tilting and abnormal gait, and body weight were scored once a week. 
A

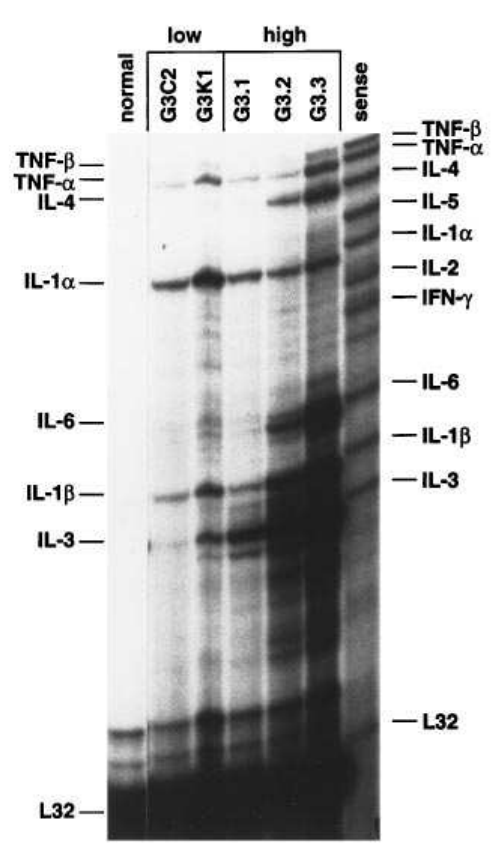

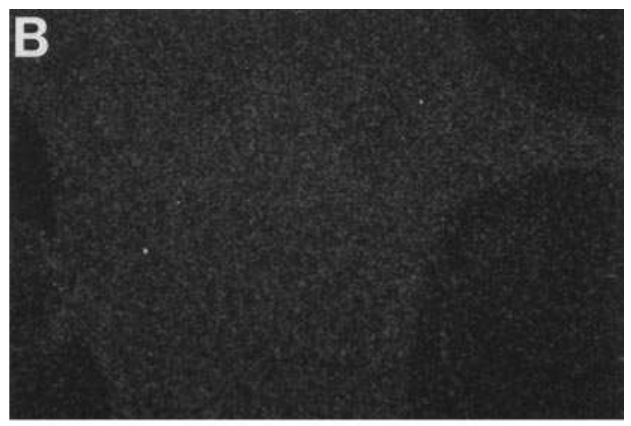

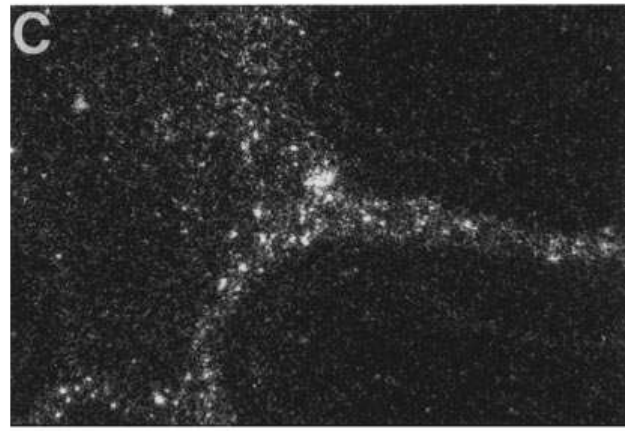

Figure 2. Analysis of cerebral transgene-encoded IL-3 expression. ( $A$ ) RNase protection analysis of cytokine mRNA levels in the brain of low expressor and high expressor GFAPIL3 mice. $(B-C)$ Distribution of IL-3 RNA expression in the brain was assessed by in situ hybridization with an ${ }^{35}$ S-labeled anti-sense IL-3 RNA probe. Sections shown represent cerebellum from a normal littermate $(B)$ and the G3K1 founder mouse $(C)$. Expression of IL-3 RNA was detectable in the transgenic specimen only and was particularly prominent in white matter tracts. $(D)$ IL-3 production from cultured astrocytes. Compared with normal littermates, significant production of IL-3 was found from astrocytes derived from $\mathrm{G} 3 \mathrm{C} 2$ mice. The production of IL-3 was markedly higher from astrocytes isolated from the cerebellum versus cerebrum $(P<0.01)$ of the $\mathrm{G} 3 \mathrm{C} 2$ animals. Values represent mean \pm SEM $(n=3) . * P<0.01$; $* * P<0.05$; compared with normal.

shaking, the solutions were centrifuged at 2,200 rpm for $4 \mathrm{~min}$ and the absorbance of the yellow upper layer was read in a spectrophotometer at $410 \mathrm{~nm}$. Activity was expressed in Units (one unit defined as one $\mu$ mole phosphate release per mg of protein per minute).

\section{Results}

Cerebral expression of IL-3 results in dose-related neurological disease. From birth, several founder generation mice displayed severe neurological disturbance with ataxia, runting, tremor, and disproportionate enlargement of the head. These animals died before reaching reproductive maturity. Pathological changes in the brain of these transgenic mice included marked cellular infiltration (with mainly macrophages, lymphocytes and to a less degree granulocytes), meningioencephalitis, hydrocephalus, gliosis, and neurodegeneration (data not shown). Two founder transgenic mice (G3K1 and G3C2) appeared healthy and normal until 4 and 5 mo of age, respectively. At this time, these animals developed abnormal motor features with head tilting, ataxia, and weakness in muscle strength. Founder G3K1 failed to breed and was killed for further analysis at 5 mo old. In contrast, founder G3C2 was mated successfully to derive a stable transgenic line. Transgenic off- spring from the G3C2 line developed a motor disorder identical to that of the parental founder. In these animals, from onset at 5-7 mo of age, the symptoms progressed rapidly over the next 2-3 mo resulting in quadriplegia and premature death. Compared with normal age-matched littermates, symptomatic G3C2 mice were significantly impaired in a quantitative test of motor function. Performance on rotating rod $(5 \mathrm{rpm})$ for female $\mathrm{G} 3 \mathrm{C} 2$ mice at 4 and 6 mo of age and normals is shown in Fig. $1 \mathrm{~A}$. Because there was no difference in rotorod performance between groups of normal mice at the two ages, the data for these groups has been pooled $(\mathrm{F}[1,8]=1.15, P>$ $0.05)$. Although the 4-mo old transgenics performed as well as normal mice, there was a significant deficit in rotorod performance in the 6-mo-old G3C2 mice observed for all three trials $(\mathrm{F}[2,15]=22, P<0.05$; followed by Newman-Keuls test $)$. There was no significant group by trial interaction. Performance on the rod rotating at $15 \mathrm{rpm}$ was also significantly impaired in the 6-mo-old G3C2 mice compared with 4-mo-old G3C2 mice and normals (4 and 6 mo old combined; $\mathrm{F}[2,15]=$ $12.5, P<0.05$, followed by Newman-Keuls test; data not shown). Studies of the incidence of motor disease (Fig. $1 B$ ) showed that female mice tended to develop symptoms earlier than males (130 d for female vs. $150 \mathrm{~d}$ for male). Moreover, pregnancy in the $\mathrm{G} 3 \mathrm{C} 2$ transgenic mice accelerated the onset 

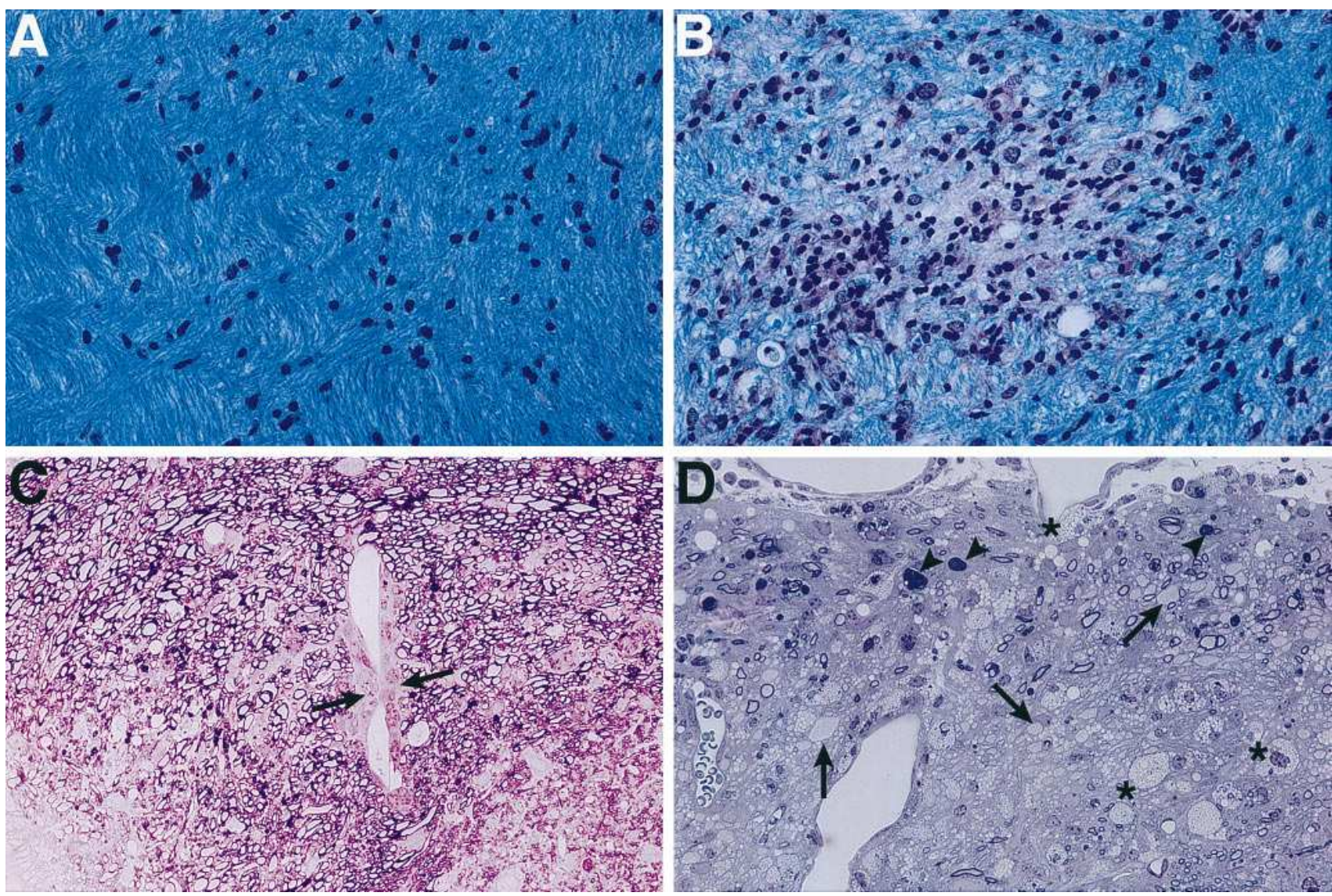

Figure 3. Focal white matter lesions and demyelination in the brain of $\mathrm{G} 3 \mathrm{C} 2$ mice. Brains were obtained from age- and sex-matched normal littermates $(A)$ and presymptomatic $(C)$ or symptomatic G3C2 mice $(B$ and $D)$. Sections from paraffin embedded control mouse cerebellar tissue $(A)$, stained with Luxol Fast Blue showing dense blue staining of the white matter characteristic of normal myelination. $\times 448$. In contrast, in a similarly stained specimen from the transgenic mouse $(B)$, a hypercellular area is visible, forming a discrete plaque-like lesion in the white matter. Note the loss of blue staining associated with this lesion indicative of demyelination. $\times 448$. Plastic sections from the brainstem of presymptomatic 4-mo-old $(C)$ and symptomatic 5.5 -mo-old $(D)$ G3C2 mice stained with methylene-blue. $\times 448$. This specimen from the presymptomatic animal shows normal myelination of white matter. However, the vessel at the center of the illustration shows perivenular cellular infiltrates (arrow). In contrast, in the symptomatic animal there is extensive loss of myelin. Demyelinated axons (arrows), myelin debris (arrowheads), and foamy macrophages (asterisks) are prominent.

of observable motor disease (not shown). Analysis of body weight revealed that $\mathrm{G} 3 \mathrm{C} 2$ mice, in contrast to their normal littermates, failed to gain weight at the onset of motor signs (Fig. $1, B$ and $C$ ). Consistent with the incidence data, female G3C2 mice also showed earlier and more pronounced changes in body weight than their male transgenic littermates (Fig. 1C).

The onset and severity of the neurological disorder in the different founders was related to the levels of transgene encoded IL-3 mRNA expression (Fig. $2 A$ ). Thus, founders with severe, early onset neurological disease had high levels of cerebral IL-3 mRNA expression. Coincidentally, in addition to IL-3, the expression of a number of other cytokine mRNAs including those for IL- $1 \alpha$, IL- $1 \beta$, IL- 4 , and TNF- $\alpha$ was also found to be significantly elevated in these mice (Fig. $2 A$ ). In all the high IL-3 expressor transgenic mice this finding paralleled the neurohistological observation of diffuse encephalitis (not shown). Founder G3K1 expressed comparatively lower levels of IL-3 mRNA in the brain, while transgenic mice of the G3C2 line showed lowest levels of cerebral IL-3 mRNA expression. Increased cerebral expression of IL- $1 \alpha$, IL-1 $\beta$ and TNF- $\alpha$ but not IL-4 mRNA was also observed in these low expressor transgenic mice. A survey of spleen, kidney, liver, tes- tis and skin from G3C2 transgenic animals failed to detect expression of IL-3 RNA in these peripheral organs (not shown). Localization of IL-3 RNA by in situ hybridization showed predominant expression in the white matter tracts of the cerebellum and brain stem in the G3K1 mouse (Fig. 2 ). In G3C2 mice, the level of IL-3 mRNA was too low to be detected by this method. However, production of IL-3 protein from astrocyte cultures derived from cerebrum $(35.5 \pm 4.3 \mathrm{pg} / \mathrm{mg})$ and cerebellum $(94.5 \pm 5.7 \mathrm{pg} / \mathrm{mg}$ ) (Fig. $2 \mathrm{D}$ ) confirmed transgene encoded IL-3 expression was also higher for astrocytes in the cerebellum in the $\mathrm{G} 3 \mathrm{C} 2$ animals.

Low levels of cerebral IL-3 production result in primary demyelination of the white matter. To examine the pathologic correlates of the neurological disorder seen in the low expressor mice, brains from G3C2 offspring of different ages were examined by light and electron microscopy. Routine histological examination failed to reveal significant alterations in asymptomatic mice. With the onset of neurological signs, focal inflammatory lesions in white matter in the cerebellum and brain stem were prominent (Fig. 3, $A$ and $B$ ). Increased numbers of mononuclear cells were observed in perivenular regions in the cerebellum. Myelin stains revealed demyelination 

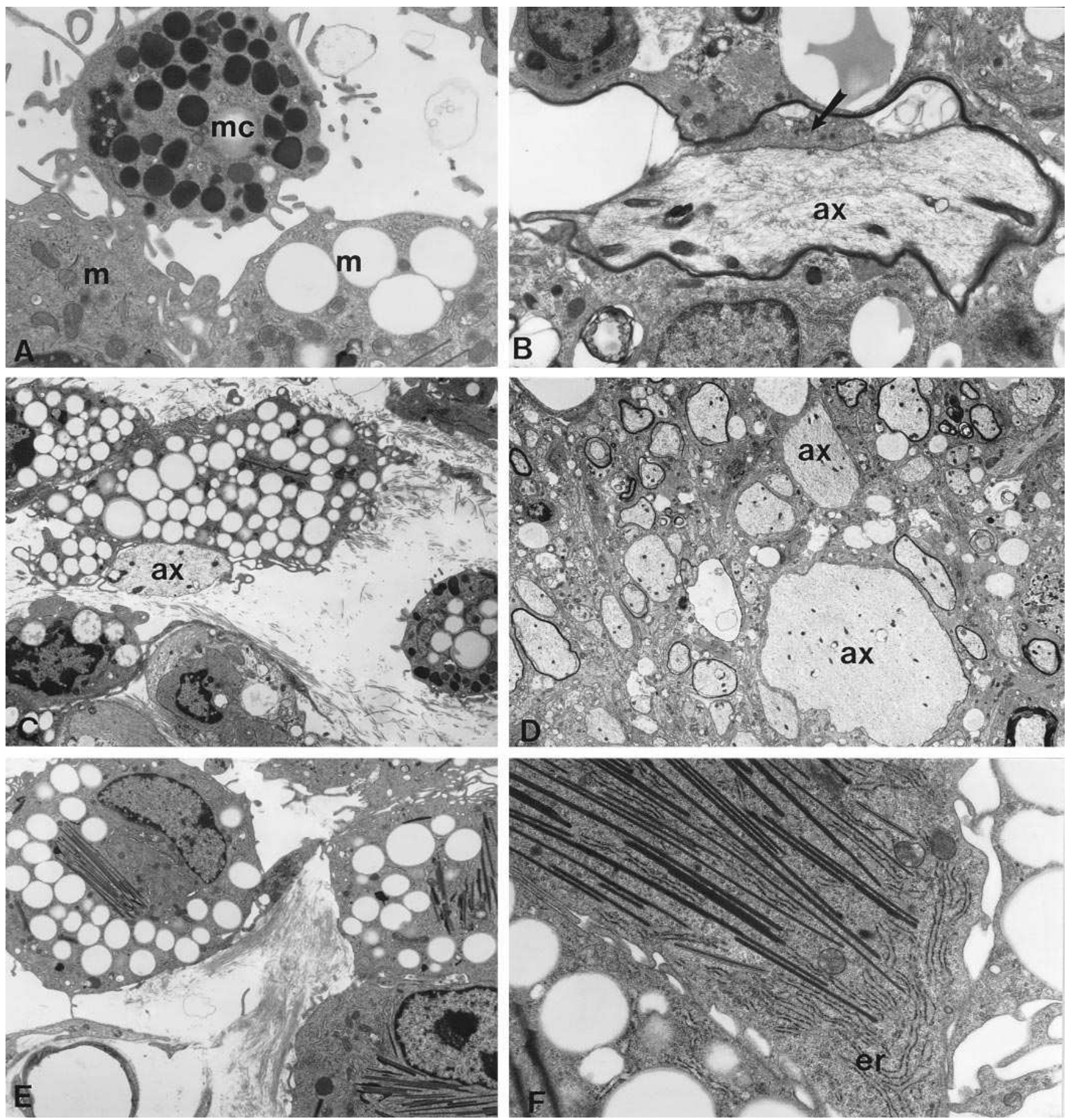

Figure 4. Ultrastructural features of demyelinating lesions in the brain stem. $(A)$ Macrophages $(\mathrm{M})$ and a mast cell (MC) represent the cell types that constitute the inflammatory infiltrate. The macrophages shown in this figure contain lipid droplets $(\times 5533)$. $(B)$ A thinly myelinated fiber undergoing demyelination with separation of myelin lamellae from the axonal surface and penetration by a process of an infiltrating cell (arrow) not connected to the myelin. The infiltrating process lies between two areas of myelinolysis $(\times 6972)$. (C) A completely demyelinated axon is surrounded by a foamy macrophage. Collagen fibrils are seen in the interstitial space $(\times 3112)$. $(D)$ Axons $(a x)$ in this field are either completely demyelinated, partially myelinated, or thinly myelinated consistent with remyelination $(\times 2490)$. $(E)$ Thin, needle-like inclusions are clustered at the center of this macrophage which also contains foamy vacuolar inclusions $(\times 3423)$. $\left({ }^{*} F\right)$ Polygonal "pole-shaped" crystalline inclusions appear in a cell in which there is ample endoplasmic reticulum (er). The inclusions are themselves enveloped by membranes of rough endoplasmic reticulum $(\times 8715)$.

in association with white matter lesions (Fig. 3, $A$ and $B$ ). Cerebellar cortices in transgenic animals with late stage disease exhibited disorganization of granular layer structure and the loss of Purkinje cells was also evident. One micron thick plastic sections from the cerebellum and brainstem of 4-mo-old mice showed occasional perivenular cellular infiltrates (Fig. $3 C$ ), as well as rare foci of active, macrophage mediated demyelination. In contrast, in symptomatic 5-mo-old transgenic mice, 

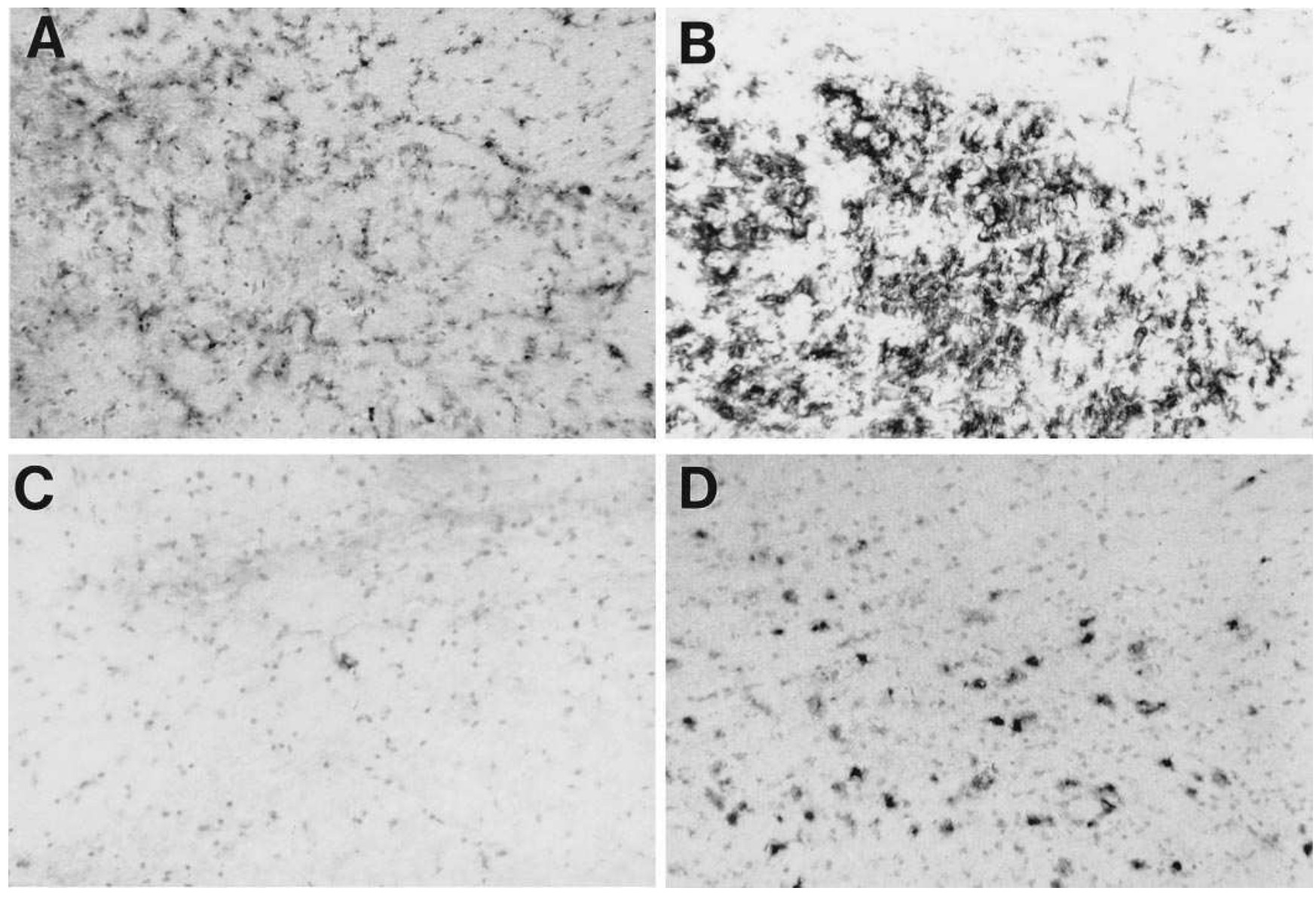

Figure 5. Prominent macrophage/microglial accumulation and activation in white matter lesions in GFAP-IL3 mice. Cryostat sections of brain from a normal $(A)$ or a symptomatic $\mathrm{G} 3 \mathrm{C} 2(B)$ mouse immunostained for Mac-1 showing a pronounced accumulation of strongly stained cells in a white matter lesion in the transgenic specimen. Adjacent sections immunostained for Ia revealed a significant increase in Ia ${ }^{+}$cells associated with white matter lesions in the G3C2 (D) specimen compared with normal $(C)$.

gross loss of myelin was manifest in white matter lesions with large numbers of demyelinated but normal appearing axons visible (Fig. $3 \mathrm{D}$ ). Large foamy macrophages were conspicuous throughout the demyelinated regions and clumps of myelin debris were also noted (Fig. $3 D$ ). Foamy macrophages were also present on the surface of the brain stem (Fig. 4A).

By electron microscopy, demyelination was seen in cerebellar and brain stem white matter associated with infiltration by macrophages (Fig. 4, $B$ and $C$ ), which appeared in the parenchyma and on the axon surface (Fig. $4 B$ ). Completely demyelinated axons were often surrounded by foamy macrophages in which the cytoplasm was filled with lipid rich vacuoles (Fig. 4 C). Contiguous axons were either partially myelinated or had inappropriately thinly myelinated sheaths consistent with remyelination (Fig. $4 \mathrm{D}$ ). The vast majority of demyelinated axons appeared normal indicating that myelin was the primary target for injury. The inflammatory infiltrate showed some distinctive abnormalities. Many of the lipid rich macrophages also contained crystalline "pole-like" inclusions in their endoplasmic reticulum (Fig. $4 E$ ). Other macrophages contained exclusively crystalline inclusions which filled their cytoplasm with needle shaped profiles that were surrounded by cisternae of endoplasmic reticulum (Fig. $4 F$ ). In the most severely affected areas of the cerebellar white matter, intense infiltration by macrophages was accompanied by necrosis and cavitary degeneration of the white matter.

Consistent with the neuropathological findings, Western blot analysis of brain lysates from late-stage symptomatic $\mathrm{G} 3 \mathrm{C} 2$ transgenic mice revealed a decrease in myelin basic protein (MBP) (71.8 $\pm 7.3 \%$ of normal mice) and SNAP25 protein ( $70.9 \pm 7.8 \%$ of normal mice) contents in cerebellum but not in cerebrum. However, the oligodendrocyte specific enzyme, $2^{\prime}, 3^{\prime}$-cyclic nucleotide phosphohydrolase (CNPase) was not changed in either content as assessed by Western blot or in total specific activity (cerebrum: $4.27 \mathrm{U}$ for normal mice vs. $4.73 \mathrm{U}$ for $\mathrm{G} 3 \mathrm{C} 2$ mice; cerebellum: $5.26 \mathrm{U}$ for normal mice vs $5.28 \mathrm{U}$ for G3C2 mice). Compared with normal controls, expression of the astrocyte protein GFAP was found to be markedly elevated $(263 \pm 31 \%)$ in cerebellum but not in cerebrum of symptomatic transgenic mice.

Macrophage/microglial activation and proliferation are coincident with demyelination in white matter. To assess the activation status of the macrophage/microglial cells in the brain of G3C2 mice, brain sections were immunostained with antibodies to the complement $\mathrm{C} 3$ receptor (Mac-1) or the MHC class II molecule (Ia). In normal mice, weakly stained Mac-1 positive cells were distributed throughout the brain, and were particularly visible in white matter regions (Fig. $5 A$ ). This prop- 

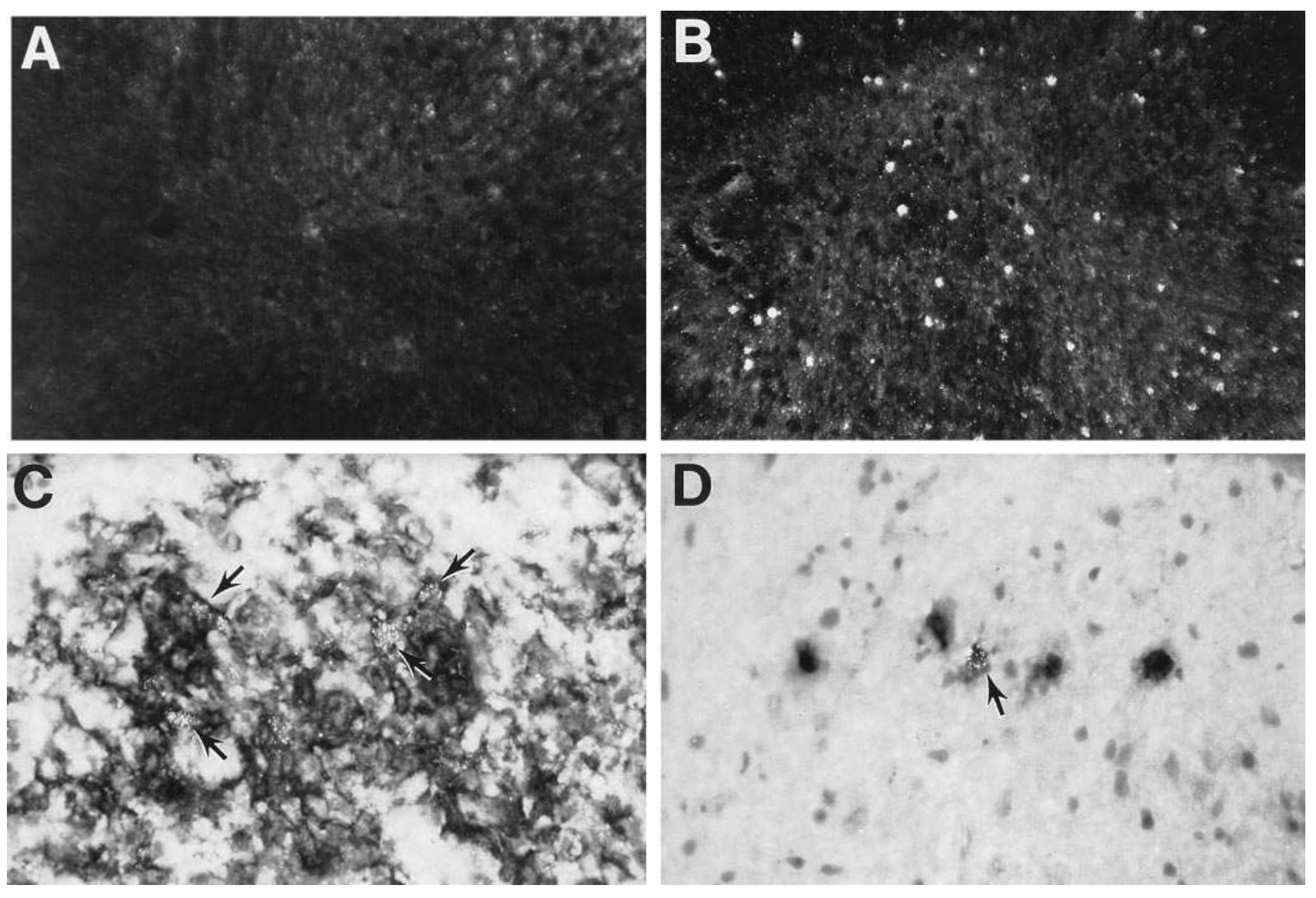

Figure 6. Marked cellular proliferation of macrophage/microglial cells in white matter lesions in GFAP-IL3 mice. Dark-field photomicrograph of autoradiographs of brain sections from normal $(A)$ or $\mathrm{G} 3 \mathrm{C} 2(B)$ mice after systemic injection of $\left[{ }^{3} \mathrm{H}\right]$ thymidine. In contrast to the absence of labeling in the normal mouse, numerous labeled cells can be seen in white matter tracts and to a lesser extent in the granular layer of the cerebellum from the transgenic animal. Combined $\left[{ }^{3} \mathrm{H}\right]$ thymidine autoradiography and immunostaining for Mac-1 $(C)$ or Ia $(D)$ of brain sections from a symptomatic G3C2 mouse. $\left[{ }^{3} \mathrm{H}\right]$ thymidine labeled Mac- $1^{+}$cells were numerous in white matter lesions (arrow) while co-labeled $\mathrm{Ia}^{+}$cells $($arrow) were also occasionally seen.

erty together with their highly ramified appearance identified these cells as resident resting microglia. Less numerous, but more strongly stained Mac-1 positive cells were associated with blood vessels. In contrast, in symptomatic transgenic mice, large numbers of intensely stained Mac-1 positive cells were present in white matter lesions (Fig. $5 B$ ). The majority of these latter cells were very large with expansive cytoplasm, compatible with hyperplastic microglia and/or the foamy macrophages noted above. A smaller number of Mac-1 positive cells in these lesions, also present at perivenular sites as well as on the brain surfaces, had a compact ameboid appearance characteristic of macrophages. In normal mice, Ia positive cells were much rarer, being restricted to perivascular sites, and were presumed to represent perivascular microglia (Fig. $5 \mathrm{C}$ ). In contrast, in transgenic mice, increased numbers of Ia positive cells also observed in the white matter lesions although their numbers were less than the Mac-1 population (Fig. $5 D$ ). In addition, increased numbers of Ia positive cells were also identified at perivenular sites and on brain surfaces (not shown). Consistent with the electron microscopic findings, immunostaining of adjacent sections for the lymphocytic markers CD4 (Th-cell), CD8 (Tc-cell) and B220 (B-cell) confirmed the absence of these cells in brain from normal and transgenic mice (not shown).
To investigate for possible macrophage/microglial cell proliferation, mice were injected with $\left[{ }^{3} \mathrm{H}\right]$ thymidine and brain sections immunolabeled for Mac-1 and Ia. Adjacent sections were also immunolabeled for the astrocyte marker GFAP. In normal mice, small numbers of labeled cells were consistently identified in the subependymal plate (not shown) and rarely, if at all, in other brain areas (Fig. $6 \mathrm{~A}$ ). These labeled cells did not stain for Mac-1, Ia or GFAP and their identity remained unknown. However, in symptomatic G3C2 mice, besides the subependymal plate, numerous labeled cells were observed particularly in focal areas of white matter of the cerebellum (Fig. $6 \mathrm{~B}$ ), brain stem and basal ganglia. The majority of $\left[{ }^{3} \mathrm{H}\right]$ thymidine labeled cells in these areas were Mac-1 positive (Fig. $6 C$ ). Rare Ia positive (Fig. $6 D$ ) and GFAP-positive (not shown) $\left[{ }^{3} \mathrm{H}\right]$ thymidine-labeled cells were also found.

Increased MHC class II gene expression and proliferation of perivascular microglia precedes development of white matter pathology. Experiments were performed to investigate the spatiotemporal expression of the MHC class II gene in the brain of $\mathrm{G} 3 \mathrm{C} 2$ mice. Compared with normal littermates, cerebral MHC class II mRNA levels increased progressively from as early as 2 mo of age in the transgenic mice (Fig. $7 A$ ). In contrast, there was no significant change in the levels of MHC class I mRNA between normal control and transgenic mice up 

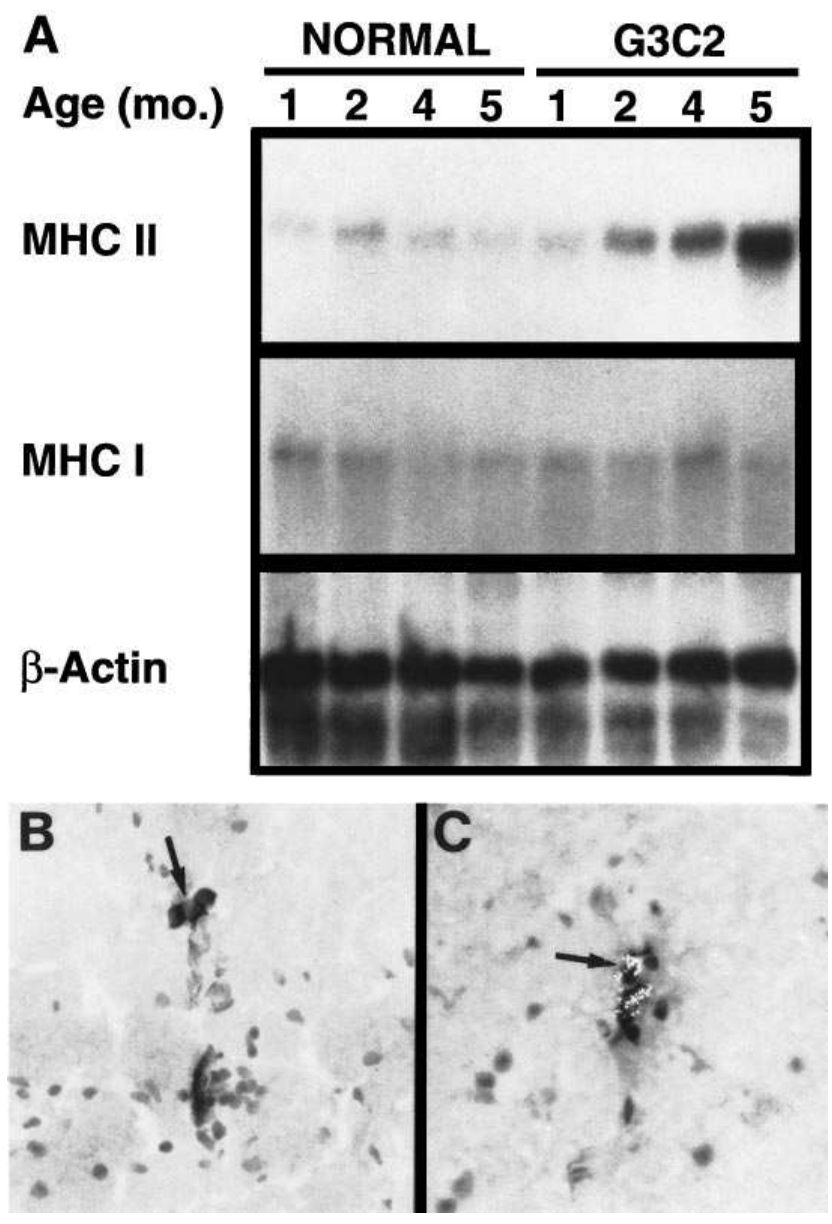

Figure 7. Early onset increased MHC-class II gene expression in the brain of G3C2 mice $(A)$ Northern blot hybridization analysis revealed increased MHC class II mRNA was detectable in the brain from transgenic mice as early as 2 mo age. In contrast, there was no significant difference in the level of MHC class I mRNA between normal or $\mathrm{G} 3 \mathrm{C} 2$ mice at any age studied. (B) Cryostat section of brain from a 3-mo-old G3C2 mouse immunostained for Ia showing increased levels of staining of perivascular microglia and accumulation of small numbers of Ia + cells with an ameboid morphology (arrow). $(C)$ Combined $\left[{ }^{3} \mathrm{H}\right]$ thymidine autoradiography and immunostaining for Ia of brain sections from a 2-mo-old G3C2 mouse showing dual labeling of perivascular cells (arrows).

to 5 mo of age. Compared with normal controls, in 2- and 3mo-old G3C2 mice, immunostaining of brain sections revealed a generalized increase of Ia protein expression by perivascular microglial cells, particularly in subcortical, cerebellar and brain stem regions. In addition, these cells frequently appeared to be hypertrophied. An associated increase in the numbers of perivascular Ia positive cells with an ameboid morphology was also noted (Fig. $7 \mathrm{~B}$ ). In parallel experiments utilizing $\left[{ }^{3} \mathrm{H}\right]$ thymidine incorporation studies combined with immunostaining, proliferating Ia positive perivascular cells were identified in the brain of 2- and 3-mo-old transgenic but not normal animals (Fig. 7 C).

\section{Discussion}

We have produced transgenic mice in which chronic expression of a macrophage/microglial activating factor, IL-3 (15,
21), was targeted to astrocytes using a GFAP-IL3 fusion gene construct. We demonstrated such mice developed distinct neurological disorders depending on the dose of transgeneencoded IL-3 expression. Thus, CNS expression of IL-3 at high levels resulted in a lethal early-onset acute neuroinflammatory disease, while CNS expression of this cytokine at low levels was associated with the development of a late-onset chronic progressive motor disorder. Significantly, in the latter case, the stable transgenic line G3C2 was established. The findings in this transgenic line indicated that the persistent CNS production of low levels of IL-3 promoted the recruitment, proliferation, and activation of macrophage/microglial cells in white matter regions with consequent demyelination. In affected regions of the cerebellum and brain stem, the presence of large numbers of normal appearing, but completely demyelinated axons as seen by electron microscopy, indicated unambiguously a process of active primary demyelination. While a small number of degenerating axons were also observed, this is characteristic of a demyelinating disease in which there is a vigorous inflammatory component (40). That this phenotype could have arisen from an insertional mutation or from some nonspecific interference with astrocyte function, created by the transgene is improbable. First, in addition to the stable G3C2 line, a similar phenotype was exhibited by an independent GFAP-IL3 founder mouse (G3K1) that was shown to also express low levels of IL-3 in the brain. Second, in the case of both the $\mathrm{G} 3 \mathrm{C} 2$ and the G3K1 transgenic mice, there was concordance between the CNS location for transgene encoded IL-3 expression and the principal sites of pathology. Third, the prominent involvement of macrophage/microglial cells in the evolution of the brain lesions seen in the GFAP-IL3 mice is consistent with the known ability of IL-3 to activate cells belonging to this lineage $(14,21)$. Finally, the pathologic and clinical profiles seen in the GFAP-IL3 mice are unique to these animals and have not been observed in other transgenic models where this GFAP construct was used to express the cytokines IL-6 $(26,32)$ and IFN- $\alpha_{1}(41)$ or the HIV coat protein gp120 (42).

Motor abnormalities in the low expressor GFAP-IL3 mice appeared with a sudden onset, typically presenting as gait disturbance starting around 5-6 mo of age, then becoming progressively more severe over the ensuing 2-3 mo, leading to complete incapacitation and premature death. Motor incoordination was estimated from rotating rod performance. This procedure permits quantification of a neurological deficit indicated by the inability of the mice to remain on a rotating rod (43). The rotating rod task has been used to characterize developmental alterations and $\mathrm{X}$-irradiation induced structural disorganization of the cerebellum and other areas involved in motor control, in laboratory rodents $(29,44)$. Since rotating rod performance has been related to cerebellar function, and IL-3 transgenic mice exhibited pathological changes in this area, cerebellar involvement in the motor deficit observed in these mice seems probable. The abrupt transition to motor disorder was further underscored by the observations that, before the appearance of an abnormal gait, physical parameters such as body weight and motor function tests indicated these animals were indistinguishable from their non-transgenic littermates. Interestingly, the onset of motor symptoms was found to occur earlier in female versus male transgenic animals. This observation, together with the recent finding that pregnancy in GFAP-IL3 mice was associated with an earlier onset of motor 
disease (unpublished observation) suggest that sex-associated factors may modulate the onset of the IL-3-induced disease process. At present the identity and mode of action of such putative factors is not known, but this issue clearly warrants further study. Significantly, the sex-associated phenomenon seen in the GFAP-IL3 mice has correlates in the human demyelinating disease, MS, where the onset is known to be earlier in females (45) and post-partum exacerbations occur more often (46).

Pathologic and molecular analysis of the brain from symptomatic low expressor GFAP-IL3 transgenic mice provided clear evidence for multiple plaque-like, white matter lesions with demyelination in the cerebellum and brain stem. Since the cerebellum and brain stem are major centers controlling motor function and coordination $(47,48)$, our findings indicated that a probable cause for the motor disease seen in the GFAP-IL3 mice was initially the development of extensive demyelination in the hind-brain regions. Although not specifically addressed by our studies here, it is also conceivable that white matter disease may have affected the spinal cord in the transgenic mice which would also contribute to loss of motor control. Preliminary ultrastructural examination of the spinal cord, has revealed the presence of demyelinating plaques in these transgenic mice (H.C. Powell and I.L. Campbell, unpublished observation). The subsequent parenchymal degeneration observed in the white matter likely compounded further the severity of the disorder leading eventually to complete incapacitation and death. Consistent with the absence of a detectable clinical phenotype, in presymptomatic transgenic animals, as late as 4 mo of age, routine histological examination and Western blotting for myelin and the synaptosomal protein SNAP-25, failed to reveal alterations in the brain. However, in this group of animals, the earliest ultrastructural morphologic abnormalities were noted with perivascular mononuclear cell accumulation and scant demyelination.

White matter lesions that developed in the GFAP-IL3 mice contained numerous intact axons devoid of myelin representative of primary demyelination. Dystrophic axons were also seen, however their small number as compared with the large number of healthy appearing demyelinated axons implied that demyelination was predominant and preceded any neuronal injury. Another common feature seen in these lesions was the presence of many axons circumscribed by a thin, even layer of myelin. This morphological profile, which is characteristic of remyelination $(49,50)$, suggested the oligodendrocytes were not only viable but also functionally active. Although we did not count oligodendrocyte numbers directly, our finding that the predominantly cell body located oligodendrocyte-specific enzyme CNPase (51) showed unaltered activity in the brain of symptomatic GFAP-IL3 mice provided further evidence for preservation of these cells. Although CNPase is also located in the myelin sheath, maintenance of this enzyme's activity has been noted in other experimental models (e.g., the shiverer mouse) $(52,53)$ where significant hypomyelination is known to occur and in which oligodendrocyte numbers are maintained. These changes in the GFAP-IL3 mice are similar to those seen in MS where extensive primary demyelination accompanied by some axonal abnormalities and remyelination is a feature of active plaque lesions (54). In the GFAP-IL3 mice, remyelination apparently persisted due to the maintenance of active oligodendrocyte activity. However, this finding contrasts with MS, where remyelination is a transient phenomenon associ- ated with new white matter plaques and is thought to eventually cease because of injury to and loss of the oligodendrocytes (55-57).

A key issue raised by our studies concerns the cause of demyelination in the GFAP-IL3 mice. As discussed above, this could not be accounted for by direct injury to and/or loss of the oligodendrocytes. On the contrary, a number of observations indicated a key role of macrophage/microglial cells in mediating demyelination. First, there was a significant accumulation of these cells within the demyelinating white matter lesions. Remarkably, these lesions were almost entirely made up of cells belonging to the monocytoid lineage, while $\mathrm{T}$ - and B-lymphocytes were absent. On the basis of ultrastructural morphology, mast cells were the only other immunoinflammatory cells to be discerned. Second, a high proportion of the macrophage/microglial cells were in an activated state as reflected by their increased expression of the complement $\mathrm{C} 3$ receptor. Third, by electron microscopy, macrophage/microglial cells could be visualized surrounding myelinated axons and in some cases seen to be actively engaged in myelin stripping. Fourth, white matter lesions contained significant numbers of swollen foamy macrophages engorged with neutral lipids, presumably as a result of engulfing myelin. Therefore, these data strongly suggest that activated macrophage/microglial cells in the GFAP-IL3 mice were the primary mediators of demyelination.

Accumulation of macrophage/microglial cells within the white matter represented a cardinal and striking feature of the GFAP-IL3 mice and as discussed above was a critical event in the development of demyelination. Macrophages $(14,15)$ and microglia (21) are known to respond to IL-3. Therefore, their accumulation in the transgenic mice is compatible with a response of these cells to the transgene encoded cytokine. This point was further illustrated by the coincidence of macrophage/ microglial accumulation with sites of transgene encoded IL-3 expression. The formation and evolution of these lesions likely resulted from multiple ongoing processes. Electron microscopic and immunostaining analysis revealed numerous macrophages on the brain surfaces as well as at perivascular sites suggesting active recruitment of these cells from the periphery was one contributing factor. Additionally, the pronounced proliferation of the Mac- $1^{+}$population observed in the white matter lesions indicated that local proliferation of the macrophage/microglial cells was also likely to be responsible for the accumulation of these cells. In addition to confirming its well described hematopoietic growth promoting properties (reviewed in reference 13) our findings suggest IL-3 is an effective and, at low concentrations, somewhat specific chemotactic and growth factor for macrophages. Why, in spite of continuous IL-3 production from birth, the recruitment and accumulation of the macrophage/microglial cells in the CNS of the low expressor transgenic mice was so protracted is unknown. It likely reflects, in part, a concentration related phenomenon since GFAP-IL3 mice with high levels of transgene expression exhibited florid and widespread mononuclear cell infiltration of the brain at an early age. In addition, compared with the periphery, the brain parenchyma is known to be extremely resistant to the proinflammatory actions (including recruitment of immunoinflammatory cells) of acutely injected LPS (58) and various cytokines and chemokines (59). This suggests as yet unidentified brain-specific factors may be involved in suppressing the potentially harmful actions of proinflammatory 
cytokines. Modulation of these factors and possibly other priming events by IL-3 in the transgenic mice may also be required to further facilitate the recruitment and infiltration of the brain by peripheral macrophages. One such priming event could involve activation of perivascular microglia. Hypertrophy, proliferation and enhanced expression of MHC class II molecules by these cells was one of the earliest changes we could detect in the brain in GFAP-IL3 animals. Induction of MHC class II expression is part of a spectrum of changes that is associated with the activation of macrophages by IL-3 (15). How, in the GFAP-IL3 mice, these early responses by the perivascular microglia might influence circulating macrophages is presently not known. It is conceivable however, that through their intimate association with the cerebrovascular endothelium, the perivascular cells might provide signals for the recruitment and promote the initial adherence of macrophages to the endothelial cell and their subsequent extravasation. Future studies aimed at delineating the functional state of the endothelium as well as the expression of key adhesion molecules will help to resolve some of these issues.

Similar to our present findings in the GFAP-IL3 mice, activated macrophage/microglial cells are implicated as key effectors in a variety of human and experimental immune-associated demyelinating neuropathies including MS (4, 56, 60, 61), Guillain-Barre syndrome (62), HIV leukoencephalopathy (63, $64)$ and EAE (65), respectively. Why myelin in particular becomes the primary target for these cells, and the mechanisms underlying the demyelination process itself, remain open questions. Experiments in vitro show that macrophages (66) and microglia (67) in addition to becoming activated, vigorously phagocytose added myelin. A critical role of the complement C3 receptor in myelin phagocytosis has been demonstrated (68). Ultrastructural evidence in the GFAP-IL3 mice revealed myelin disruption by macrophage/microglial cells indicative of direct physical involvement of these cells in the demyelination process. Moreover, the prominent hyperexpression of complement $\mathrm{C} 3$ receptor by macrophage/microglial cells observed in the white matter lesions of the GFAP-IL3 mice suggest there may be a role for this molecule in the coupling and subsequent amputation of the myelin lamellae.

Demyelination in the GFAP-IL3 mice might also result indirectly from the release of soluble factors. Activated macrophages and microglia are known to produce a spectrum of soluble factors including cytokines, serine proteases, prostaglandins and reactive oxygen species that under certain conditions may mediate tissue injury (12). Disease progression in the GFAP-IL3 mice was found to be associated with increased expression of IL- $1 \alpha$ and to a lesser extent IL- $1 \beta$ and TNF- $\alpha$ mRNAs. While the presence of these cytokine RNAs does not necessarily infer their activity at the protein level, it is notable in the case of TNF- $\alpha$ that this cytokine may damage myelin and be toxic to oligodendrocytes in vitro $(69,70)$. Recent evidence suggests the toxic actions of TNF- $\alpha$ to oligodendrocytes in vitro are mediated in part via the induction of nitric oxide (NO) (71). However, in recent studies we were unable to detect iNOS mRNA in brain from symptomatic G3C2 mice (I.L. Campbell, unpublished observation). Therefore, NO is not likely to be involved in the pathogenesis of macrophage/microglial mediated demyelination in this animal model.

In many respects, the molecular and cellular pathologic manifestations exhibited by the GFAP-IL3 mice show remarkable overlap with those in the active plaque lesions of MS.
Thus, the animal model closely resembles the histopathology of acute fulminant MS where there is frequently heavy macrophage infiltration with minimal perivascular $\mathrm{T}$ cell infiltration (72). Furthermore, in MS, reactive macrophage/microglial cells with increased MHC class II and complement C3 receptor expression are the predominant cells found at the leading edge of demyelinating lesions $(4,56,60,73)$. Consistent with their effector role in demyelination, fine structural studies illustrate macrophages in MS lesions separating and engulfing myelin lamellae, as well as the presence of numerous foamy macrophages engorged with neutral lipid material $(54,74,75)$. The presence of intracisternal "pole like" bodies within macrophages present in active MS plaques appears to represent a unique morphological feature of this disorder (54). Interestingly, almost identical intracisternal inclusions were observed in macrophages in white matter lesions in the GFAP-IL3 mice. While the identity and function of these unusual structures are unknown, the transgenic mice now provide an opportunity to establish their nature. Mast cells are known to respond to IL-3 (13) and were present in white matter lesions in the transgenic mice. These cells which are infrequently if at all seen in the normal human brain, have been reported in demyelinating MS plaques (76). Finally, as discussed above, remyelination which was prominent in the transgenic mice is also seen in active MS plaque lesions. These similarities between the human and transgenic murine demyelinating disorders suggest there may be underlying common pathogenetic mechanisms, perhaps involving IL-3 or a related cytokine. An implication from our findings is that one role of the putative autoreactive $\mathrm{T}$ cells that are thought to contribute to the development of MS (57, 77), may be to provide a chronic source of macrophage recruiting and activating cytokines such as IL-3. Although IL-3 and other functionally related cytokines such as GM-CSF and CSF-1 are known to be produced by activated T cells (13), to date we are not aware of any studies that have examined for the presence of these cytokines in the active plaques of MS. However, in the related experimental disorder of EAE in mice, expression of CSF-1 is increased markedly in spinal cord before maximal clinical expression of disease (78). Furthermore, a positive correlation was recently reported between myelin basic protein-specific T cell production of IL-3 and the encephalitogenic potential of these cells when adoptively transferred to susceptible mice (79).

In conclusion, transgenic mice with low levels of cerebral IL-3 expression develop in later life a progressive motor disorder as a result of a vigorous $\mathrm{T}$ cell-independent macrophage/ microglia-mediated demyelination process. Many of the clinicopathologic manifestations of this disorder show a striking resemblance to those observed in human inflammatory demyelinating diseases, particularly acute fulminant multiple sclerosis, suggesting the GFAP-IL3 transgenic mouse is a potentially valuable new model to study the role of macrophage/microglia in the pathogenesis of CNS demyelinating disease.

\section{Acknowledgments}

We thank Dr. Nai-Chen Yu for assistance with the preparation of astrocyte cell cultures, Ms. Laurie Turbeville and Anna Stalder for technical assistance and Jenny Price for her assistance in the development of the transgenic mice. We thank Drs. Monte V. Hobbs, Michael C. Wilson, and Monica Carson at the Scripps Research Insti- 
tute for providing the cytokine RPA probe, SNAP-25 antibodies and CNPase antibody, respectively.

This paper is manuscript number 9302-NP from the Scripps Research Institute. This study was supported by U.S. Public Health Service Grants MH-47680 and MH-50426 to I.L. Campbell.

\section{References}

1. Lawson, L.J., V.H. Perry, P. Dri, and S. Gordon. 1990. Heterogeneity in the distribution and morphology of microglia in the normal adult mouse brain. Neurosci. 39:151-170.

2. Ling, E.-A., and W.-C. Wong. 1993. The origin and nature of ramified and amoeboid microglia: a historical review and current concepts. GLIA. 7:918.

3. Nakajima, K., and S. Kohsaka. 1993. Functional roles of microglia in the brain. Neurosci. Res. 17:187-203.

4. Boyle, E.A., and P.L. McGeer. 1990. Cellular immune response in multiple sclerosis plaques. Am. J. Pathobiol. 137:575-584.

5. McGeer, P.L., S. Itagaki, B.E. Boyes, and E.G. McGeer. 1988. Reactive microglia are positive for HLA-DR in the substantia nigra of Parkinson's and Alzheimer's disease brains. Neurol. 38:1285-1291.

6. McGeer, P.L., T. Kawamate, D.G. Walker, H. Akiyama, I. Tooyama, and E.G. McGeer. 1993. Microglia in degenerative neurological disease. GLIA. 7: 84-92.

7. Dickson, D.W., L.A. Mattiace, K. Kure, K. Hutchins, W.D. Lyman, and C.F. Brosnan. 1991. Biology of Disease: Microglia in human disease, with an emphasis on acquired immune deficiency syndrome. Lab. Invest. 64:135-156.

8. Chiang, C.S., W.H. McBride, and H.R. Withers. 1993. Radiation-induced astrocytic and microglial responses in mouse brain. Radiother. Oncol. 29:60-68.

9. Giulian, D., K. Vaca, and M. Corpuz. 1993. Brain glia release factors with opposing actions upon neuronal survival. J. Neurosci. 13:29-37.

10. Davis, E.J., T.D. Foster, and W.E. Thomas. 1994. Cellular forms and functions of brain microglia. Br. Res. Bull. 34:73-78.

11. Colton, C.A., and D.L. Gilbert. 1993. Microglia, an in vivo source of reactive oxygen species in the brain. Adv. Neurol. 59:321-326.

12. Banati, R.B., J. Gehrmann, P. Schubert, and G.W. Kreutzberg. 1993. Cytotoxicity of microglia. GLIA. 7:111-118.

13. Schrader, J.W. 1986. The pan specific hemopoietin of activated T-lymphocytes (interleukin-3). Ann. Rev. Immunol. 4:205-230.

14. Frendl, G. 1992. Interleukin 3: from colony-stimulating factor to pluripotent immunoregulatory cytokine. J. Immunol. 14:421-430.

15. Frendl, G., and D.I. Beller. 1990. Regulation of macrophage activation by IL-3. J. Immunol. 144:3392-3399.

16. Oster, W., J. Frisch, U. Nicolay, and G. Schulz. 1988. Interleukin-3: biological effects and clinical impact. Cancer. 67:2712-2717.

17. Kurzrock, R., M. Talpaz, Z. Estrov, M.G. Rosenblum, and J.U. Gutterman. 1991. Phase 1 study of human recombinant interleukin-3 in patients with bone marrow failure. J. Clin. Oncol. 9:1241-1250.

18. Aglietta, M., F. Sanavio, A. Stacchini, S. Morelli, L. Fubini, A. Severino, P. Pasquino, C. Volta, S. Bretti, S. Tafuto et al. 1993. Interleukin-3 in vivo: kinetics of response of target cells. Blood. 82:2054-2061.

19. McBride, W.H., G.D. Dougherty, G.D. Wallis, O. Econo J.S., and C.-S. Chiang. 1994. Interleukin-3 in gene therapy of cancer. Folia Biologica. 40:6273.

20. Pulaski, B.A., A.J. McAdam, E.K. Hutter, S. Biggar, E.M. Lord, and J.G. Frelinger. 1993. Interleukin-3 enhances the development of tumor reactive cytotoxic cells by a CD4-dependent mechanism. Cancer Res. 53:2112-2117.

21. Gebicke-Haerter, P.J., K. Appel, G.D. Taylor, A. Schobert, I.N. Rich, H. Northoff, and M. Berger. 1994. Rat microglial interleukin-3. J. Neuroimmunol. 50:203-214

22. Appel, K., M. Buttini, A. Sauter, and P.J. Gebicke-Haerter. 1995. Cloning of rat interleukin-3 $\beta$-subunit from cultured microglia and its RNA expression in vivo. J. Neurosci. 15:5800-5809.

23. Lee, T.T., F.C. Martin, and J.E. Merrill. 1993. Lymphokine induction of rat microglia multinucleated giant cell formation. GLIA. 8:51-61.

24. Araujo, D.M., and P.A. Lapchak. 1994. Induction of immune system mediators in the hippocampal formation in Alzheimer's and Parkinson's diseases: selective effects on specific interleukins and interleukin receptors. $\mathrm{Neu}$ rosci. 61:745-754.

25. Campbell, I.L. 1994. Cytokines in the pathogenesis of CNS disease. Studies in transgenic mice. Int. J. Dev. Neurosci. Suppl.1 12:66.

26. Campbell, I.L., C.R. Abraham, E. Masliah, P. Kemper, J.D. Inglis, M.B.A. Oldstone, and L. Mucke. 1993. Neurologic disease induced in transgenic mice by the cerebral overexpression of interleukin 6. Proc. Natl. Acad. Sci. USA. 90:10061-10065.

27. Mucke, L., M.B.A. Oldstone, J.C. Morris, and M.I. Nerenberg. 1991. Rapid activation of astrocyte-specific expression of GFAP-lacZ transgene by focal injury. New Biol. 3:465-474

28. Jones, B.J., and D.J. Roberts. 1968. The quantitative measurement of motor incoordination in naive mice using an accelerating rotarod. J. Pharm. Pharmac. 20:302-304.

29. Laffan, E.W., C.A. Lisciotto, D.A. Gapp, and D.A. Weldon. 1989. Development of rotorod performance in normal and congenitally hypothyroid mutant mice. Behav. Neural. Biol. 52:411-416.

30. Badley, J.E., G.A. Bishop, T. St. John, and J.A. Frelinger. 1988. A simple, rapid method for the purification of poly $\mathrm{A}^{+}$RNA. Biotechniques. 6:114116 .

31. Hobbs, M.V., W.O. Weigle, D.J. Noonan, B.E. Torbett, R.J. McEvilly, R.J. Koch, G.J. Cardenas, and D.N. Ernst. 1992. Patterns of cytokine gene expression by CD4+ T cells from young and old mice. J. Immunol. 150:36023068 .

32. Chiang, C.-S., A. Stalder, A. Samimi, and I.L. Campbell. 1994. Reactive gliosis as a consequence of interleukin-6 expression in the brain. Studies in transgenic mice. Dev. Neurosci. 16:212-221.

33. Campbell, I.L., M.V. Hobbs, P. Kemper, and M.B.A. Oldstone. 1994. Cerebral expression of multiple cytokine genes in mice with lymphocytic choriomeningitis. J. Immunol. 152:716-723.

34. Benoist, C.O., D.J. Mathis, M.R. Kanter, V.E. Williams, and H.O. McDevitt. 1983. Regions of allelic hypervariability in the murine A alpha immune response gene. Cell. 34:169-177.

35. Reyes, A.A., M. Schold, and R.B. Wallace. 1982. The complete amino acid sequence of the murine transplantation antigen $\mathrm{H}-2 \mathrm{Db}$ as deduced by molecular cloning. Immunogenetics. 16:1-9.

36. Tokunaga, K., H. Taniguchi, K. Yoda, M. Shimizu, and S. Sakiyama. 1986. Nucleotide sequence of a full-length cDNA for mouse cytoskeletal betaactin mRNA. Nucleic Acids Res. 14:2829.

37. Wilson, M.C., and G.A. Higgins. 1989. In Situ hybridization. Neuromethods. 16:239-284.

38. Chiang, C.-S., and W.H. McBride. 1991. Radiation-enhanced TNF production by murine brain cells. Brain Res. 566:265-269.

39. Prohaska, J.R., D.A. Clark, and W.W. Wells. 1973. Improved rapidity and precision in the determination of brain $2^{\prime}, 3^{\prime}$-cyclic nucleotide- $3^{\prime}$-phosphohydrolase. Anal. Biochem. 56:272-282.

40. Powell, H.C., R.R. Myers, A.P. Mizisin, T. Olee, and S.W. Brostoff. 1991. Response of the axon and barrier endothelium to experimental allergic neuritis induced by autoreactive T cell lines. Acta Neuropathol. 82:364-377.

41. Campbell, I.L., L. Mucke, and K. Sandberg. 1993. Cerebral overexpression of interleukin-6 or interferon- $\alpha_{1}$ induces distinct neuropathology in transgenic mice. Soc. Neurosci. Abstr. Vol.19 (Part 1):225.

42. Toggas, S.M., E. Masliah, E.M. Rockenstein, G.F. Rall, C.R. Abraham, and L. Mucke. 1994. Central nervous system damage produced by expression of the HIV-1 coat protein gp120 in transgenic mice. Nature (Lond.). 367:188-193.

43. Dunham, N.W., and T.S. Miya. 1957. A note on a simple apparatus for detecting neurological deficit in rats and mice. J. Am. Pharmaceut. Assn. 46: 208-209.

44. Pellegrino, L.J., and J. Altman. 1979. Effects of differential interference with postnatal cerebellar neurogenesis on motor performance, activity level and maze learning of rats: a developmental study. J. Comp. Physiol. Psychol. 93:1-33.

45. Leibowitz, U., and M. Alter. 1973. Multiple sclerosis. In Clinical Studies of Multiple Sclerosis in Israel. U. Leibowitz and M. Alter, editors. North-Holland Publishing Company, New York. 25-35.

46. Nelson, L.M., G.M. Franklin, and M.C. Jones. 1984. Risk of multiple sclerosis exacerbation during pregnancy and breast-feeding. J. Am. Med. Assoc. 259:3441-3443.

47. Thack, W.T., H.P. Goodkin, and J.G. Keating. 1992. The cerebellum and the adaptive coordination of movement. Ann. Rev. Neurosci. 62:403-442.

48. Lang, A.E. 1991. Movement disorder symptomatology. In Neurology in Clinical Practice: principles, Diagnosis and Management. W.G. Bradley, R.B. Doroff, G.M. Fenichel, and C.D. Marsden, editors. Butterworth-Heinemann Reed, New York. 320-321.

49. Prineas, J.W., R.O. Barnard, E.E. Kwon, L.R. Sharer, and E.-S. Cho. 1993. Multiple sclerosis: remyelination of nascent lesions. Ann. Neurol. 33:137151

50. Raine, C.S., and E. Wu. 1993. Multiple sclerosis: Remyelination in acute lesions. J. Neuropathol. Exper. Neurol. 52:199-204.

51. Shapira, R., W.C. Mobley, S.B. Thiele, M.R. Wilhelmi, A. Wallace, and R.F. Kibler. 1978. Localization of $2^{\prime}, 3^{\prime}$-cyclic nucleotide-3'-phosphohydrolase of rabbit brain by sedimentation in a continuous sucrose gradient. J. Neurochem. 30:123-131.

52. Bird, T.D., D.F. Farrell, and S.M. Sumi. 1978. Brain lipid composition of the shiverer mouse: (genetic defect in myelin development). J. Neurochem. 31: 387-391.

53. Mikoshiba, K., K. Nagaike, and Y. Tsukada. 1980. Subcellular distribution and developmental change of $2^{\prime}, 3^{\prime}$-cyclic nucleotide $3^{\prime}$-phosphohydrolase in the central nervous system of the myelin-deficient shiverer mutant mice. $J$. Neurochem. 1980:465-470.

54. Rodriguez, M., and B. Scheithauer. 1994. Ultrastructure of multiple sclerosis. Ultrastruct. Pathol. 18:3-13.

55. Prineas, J.W., R.O. Barnard, T. Revesz, E.E. Kwon, L. Sharer, and E.-S. Cho. 1993. Multiple sclerosis. Pathology of recurrent lesions. Brain. 116:681-693. 
56. Adams, C.W.M., R.N. Poston, and S.J. Buk. 1989. Pathology, histochemistry and immunocytochemistry of lesions in acute multiple sclerosis. $J$. Neurol. Sci. 92:291-306.

57. ffrench-Constant, C. 1994. Pathogenesis of multiple sclerosis. Lancet. 343:271-275.

58. Andersson, P.-B., V.H. Perry, and S. Gordon. 1992. The acute inflammatory response to lipopolysaccharide in CNS parenchyma differs from that in other body tissues. Neurosci. 48:169-186.

59. Andersson, P.-B., V.H. Perry, and S. Gordon. 1992. Intracerebral injection of proinflammatory cytokines or leukocyte chemotaxins induces minimal myelomonocytic cell recruitment to the parenchyma of the central nervous system. J. Exp. Med. 176:255-259.

60. Hauser, S.L., A.K. Bhan, F. Gilles, M. Kemp, C. Kerr, and H.L. Weiner. 1986. Immunohistochemical analysis of the cellular infiltrate in multiple sclerosis lesions. Ann. Neurol. 19:578-587.

61. Li, H., J. Newcombe, N.P. Groome, and M.L. Cuzner. 1993. Characterization and distribution of phagocytic macrophages in multiple sclerosis plaques. Neuropathol. Appl. Neurobiol. 19:214-223.

62. Griffin, J.W., G. Stoll, C.Y. Li, W. Tyro, and D.R. Cornblath. 1990. Macrophage responses in inflammatory demyelinating neuropathies. Ann. Neurol. 27:S64-S68.

63. Gray, F., and M.C. Lescs. 1993. HIV-related demyelinating disease. Eur. J. Med. 2:89-96.

64. Smith, T.W., U. DeGirolami, D. Hein, F. Bolgert, and J.-J. Hauw. 1990. Human immunodeficiency virus (HIV) leukoencephalopathy and the microcirculation. J. Neuropathol. Exp. Neurol. 49:357-370.

65. Brosnan, C.F., M.B. Bornstein, and B.R. Bloom. 1981. The effects of macrophage depletion on the clinical and pathologic expression of experimental allergic encephalomyelitis. J. Immunol. 126:614-620.

66. Friede, R.L., and W. Bruck. 1993. Macrophage functional properties during myelin degradation. Adv. Neurol. 59:327-336.

67. Williams, K., E. Ulvestad, A. Waage, J.P. Antel, and J. McLaurin. 1994. Activation of adult human derived microglia by meylin phagocytosis in vitro. $J$. Neurosci. Res. 38:433-443.
68. Bruck, W., and R.L. Friede. 1990. Anti-macrophage CR3 antibody blocks myelin phagocytosis by macrophages in vitro. Acta Neuropathol. 80:415418

69. Selmaj, K., C.S. Raine, M. Farooq, W.T. Norton, and C.F. Brosnan. 1991. Cytokine cytotoxicity against oligodendrocytes. J. Immunol. 147:1522-1529.

70. Louis, J.-C., E. Magal, S. Takayama, and S. Varon. 1993. CNTF protection of oligodendrocytes against natural and tumor necrosis factor-induced death. Science (Wash. DC). 259:689-692.

71. Merrill, J.E., L.J. Ignarro, M.P. Sherman, J. Melinek, and T.E. Lane. 1993. Microglial cell cytotoxicity of oligodendrocytes is mediated through nitric oxide. J. Immunol. 151:2132-2141.

72. Nesbit, G.M., G.S. Forbes, B.W. Scheithauer, and H. Okazaki. 1991. Multiple sclerosis: Histopathologic and MR and/or CT correlation in 37 cases at biopsy and three cases at autopsy. Radiology. 180:467-474.

73. Newcombe, J., H. Li, and M.L. Cuzner. 1994. Low density lipoprotein uptake by macrophages in multiple sclerosis plaques: implications for pathogenesis. Neuropathol. Appl. Neurobiol. 20:152-162.

74. Prineas, J.W., and R.G. Wright. 1978. Macrophages, lymphocytes and plasma cells in the perivascular compartments in chronic multiple sclerosis. Lab. Invest. 48:581-589.

75. Lampert, P.W. 1978. Autoimmune and virus-induced demyelinating diseases. Am. J. Pathol. 91:176-198.

76. Toms, R., H.L. Weiner, and D. Johnson. 1990. Identification of IgE-positive cells and mast cells in frozen sections of multiple sclerosis brains. J. Neuroimmunol. 30:169-177.

77. Martin, R., H.F. McFarland, and D.E. McFarlin. 1992. Immunological aspects of demyelinating diseases. Ann. Rev. Immunol. 10:153-187.

78. Hulkower, K., C.F. Brosnan, D.A. Aquino, W. Cammer, S. Kulshretha, M.P. Guida, D.A. Rapoport, and J.W. Berman. 1993. Expression of CSF-1, c-fms, and MCP-1 in the central nervous system of rats with experimental allergic encephalomyelitis. J. Immunol. 150:2525-2533.

79. Zhao, M.-L., J.-Q. Xia, and R.B. Fritz. 1993. Interleukin 3 and encephalitogenic activity of SJL/J myelin basic protein-specific T cell lines. J. Neuroimmunol. 43:69-78. 